\title{
Voluntary turnover, volatility in voluntary turnover, and labor productivity
}

Van Beveren, Ilke, Vanormelingen, Stijn, De Winne, Sophie \& Sels, Luc

\section{ABSTRACT}

Voluntary turnover is a frequently studied employee outcome in articles on the relationship between HRM and firm performance. The main assumption underlying these articles is "less voluntary turnover is better". Recent research questioned this assumption and showed that the relationship between turnover and firm performance might be more complex than assumed thus far in strategic HRM literature. The purpose of this article is to add to the discussion and unravel this complex relationship. Based on Iongitudinal data of Belgian firms over the period 1999 to 2008, we study the impact of both the level of voluntary turnover and the volatility in voluntary turnover on labor productivity. The results suggest that the relation between voluntary turnover and productivity is not linear. Labor productivity increases at low levels of turnover and decreases afterwards. At high levels of turnover the marginal impact of turnover is estimated to be zero. Moreover, an increase in the volatility of voluntary turnover is associated with a decrease in labor productivity. 